\title{
A Two-Step Approach to Investigate Dividend Policy: Evidence from Vietnamese Stock Market
}

\author{
Pascal Alphonse ${ }^{1} \&$ Quoc Trung Tran ${ }^{2,3}$ \\ ${ }^{1}$ University of Lille North of France-Skema Business School-LSMRC, Lille, France \\ ${ }^{2}$ University of Lille North of France, Lille, France \\ ${ }^{3}$ Ho Chi Minh City Campus, Foreign Trade University, Ho Chi Minh City, Vietnam \\ Correspondence: Quoc Trung Tran, Ho Chi Minh City Campus, Foreign Trade University, 15 D5 Street, Ward 25, \\ Binh Thanh District, Ho Chi Minh City, Vietnam. Tel: 84-909-574-029. E-mail: quoctrungftu@gmail.com
}

Received: December 12, 2013

Accepted: January 8, $2014 \quad$ Online Published: February 25, 2014

doi:10.5539/ijef.v6n3p16

URL: http://dx.doi.org/10.5539/ijef.v6n3p16

\begin{abstract}
Dividend policy includes two steps of making decisions, namely dividend payment and dividend magnitude; however, several prior studies focus on only one in two steps. This study investigates dividend policy in Vietnamese stock market with Heckman's two-step regression approach which fixes the selection bias caused by censored research data. Research findings show that in the first step, likelihood of dividend payment is positively affected by profitability, firm size and earned/contributed capital mix and state control while it is negatively related to investment opportunities, stock liquidity and insider ownership. In the second step, investment opportunities and insider retention have a negative impact on dividend yields while leverage has negative and positive impacts on payout ratio and dividend yield respectively. Contrary to free cash flow hypothesis, free cash flows to total assets ratio is negatively related to payout ratio.
\end{abstract}

Keywords: dividend policy, two-step approach, Vietnamese stock market

\section{Introduction}

Dividend policy is one of the most debatable topics in corporate finance. Miller and Modigliani (1961), Miller and Scholes (1978) posit the irrelevance of dividends under perfect markets. However, later studies find that dividends are relevant and there are many determinants of dividend policy in both developed and emerging stock markets. In addition, dividend policy includes two steps of making decisions. The first step is decisions of paying or not paying dividends and the second step is decisions of dividend magnitude if firms decide to pay. However, several prior studies only focus on dividend payments (DeAngelo, DeAngelo, \& Stulz, 2006; Fama \& French, 2001; Fatemi \& Bildik, 2012; Grullon \& Michaely, 2002; Philip \& Zhang, 2013) or dividend levels (Abor \& Fiador, 2013; Chang \& Rhee, 1990; Holder, Langrehr, \& Hexter, 1998; P. Jiraporn, Kim, \& Kim, 2011; Rozeff, 1982)

This study investigates the impact of firm characteristics on dividend policy in Vietnamese stock market, an emerging market established in 2000, with two steps of dividend paying decisions. Firstly, we examine the extent to which firm characteristics (profitability, firm size, investment opportunities and earned/contributed capital mix), stock liquidity and ownership structure (insider ownership and state control) affect dividend paying behavior. Secondly, we investigate the impact of investment opportunities, stock liquidity, free cash flow, insider ownership and state control on dividend magnitude measured by dividend payout ratio and dividend yield. The research sample includes 1339 observations in Ho Chi Minh Stock Exchange (HSX) and Ha Noi Stock Exchange (HNX) over the period from 2006 to 2011. From econometric perspective, the research data is censored since dividends are continuous to the right of zero. There is selection bias if OLS regression is applied for the full sample of non-payers and payers or the subsample of payers. Hence, Heckman's two-step regression approach is employed to fix the selection bias (Wooldridge, 2010). 


\section{Background Information on Vietnamese Stock Market}

Table 1. Counts of listed firms in Vietnamese stock market

\begin{tabular}{lccccccc}
\hline Year & 2005 & 2006 & 2007 & 2008 & 2009 & 2010 & 2011 \\
\hline HSX & 23 & 81 & 107 & 135 & 175 & 253 & 275 \\
HNX & 8 & 86 & 116 & 171 & 236 & 333 & 356 \\
Total & 31 & 167 & 223 & 306 & 411 & 586 & 631 \\
\hline
\end{tabular}

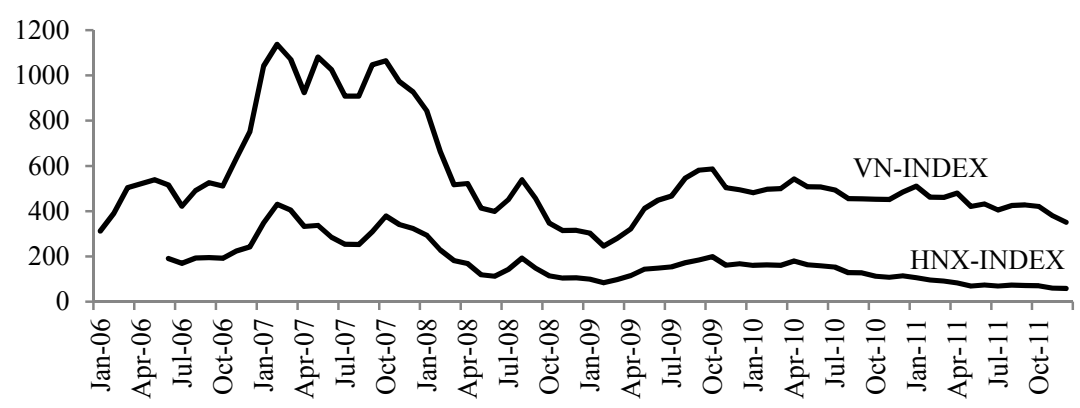

Figure 1. Performance of VN-INDEX and HNX-INDEX from 2006 to 2011

Vietnamese stock market includes Ho Chi Minh City Stock Exchange (HSX) and Ha Noi Stock Exchange (HNX) which were established in 2000 and 2005 respectively. During the period from 2000 to 2005, there are about 30 corporations listed in both stock exchanges. However, Vietnamese stock market started to develop rapidly in 2006. The number of listed companies in 2006 was over 5 times higher than in 2005 (Table 1). In addition, VN-INDEX and HNX-INDEX which are performance indices of HSX and HNX respectively rose dramatically from June 2006 and reached their peaks in the first quarter of 2007. Nevertheless, after two years of booming, the market experienced bubble burst in 2008 with sharp deteriorations in both stock exchanges. After a slight recovery in 2009, Vietnamese stock market tended to decline in the following years due to the impact of economic recession (Figure 1).

Besides, from 2000 Vietnam government promoted policy of reforming state-owned enterprises (SOEs). Many $100 \%$ SOEs were requested to sell their stocks to the public at the maximum of $49 \%$ and be listed on stock exchanges. Consequently, Vietnamese stock market has a high percentage of state-controlled firms which have more than $50 \%$ of shares held by State or its agency. Over $30 \%$ of listed firms are state-controlled.

According to Vietnam Enterprise Law, firms are allowed to retain $100 \%$ earnings or distribute their earnings in forms of cash dividends, retained earnings, stock dividends and share repurchases. Like other emerging markets, Vietnamese stock market has a high proportion of paying firms which is over $80 \%$ during the period from 2006 to 2011 .

Table 2. Vietnam tax policy on dividends and capital gains from 2006 to 2011

\begin{tabular}{|c|c|c|c|c|c|c|}
\hline & \multicolumn{2}{|c|}{$1^{\text {st }}$ sub-period } & \multicolumn{2}{|c|}{$2^{\text {nd }}$ sub-period } & \multicolumn{2}{|c|}{$3^{\text {rd }}$ sub-period } \\
\hline & Dividends & Capital gains & Dividends & Capital gains & Dividends & Capital gains \\
\hline Individual investors & $0 \%$ & $0 \%$ & $\begin{array}{c}0 \%^{\mathrm{a}} \\
\text { and } 5 \%\end{array}$ & $\begin{array}{c}0 \%^{\mathrm{a}} \text { and } \\
20 \% \text { or } 0.1 \% \text { of } \\
\text { selling price }^{\mathrm{b}}\end{array}$ & $0 \%$ & $\begin{array}{c}10 \% \text { or } 0.05 \% \text { of } \\
\text { selling price }\end{array}$ \\
\hline $\begin{array}{l}\text { Vietnamese } \\
\text { institutional investors }\end{array}$ & $0 \%$ & $28 \%$ & $0 \%$ & $25 \%$ & $0 \%$ & $25 \%$ \\
\hline $\begin{array}{l}\text { Foreign institutional } \\
\text { investors }\end{array}$ & $0 \%$ & $0.1 \%$ of selling price & $0 \%$ & $0.1 \%$ of selling price & $0 \%$ & $0.1 \%$ of selling price \\
\hline
\end{tabular}

Note: 1st sub-period is from January 2006 to December 2008; 2nd sub-period is from January 2009 to July 2011; 3rd sub-period is from August 2011 to December 2011; a From to January 2009 to December 2009; b From January 2010 to July 2011. Source: Circular No. 100/2004/TT-BTC, Law No. 09/2003/QH11, Law No. 14/2008/QH12, Law No. 04/2007/QH12, Circular No. 134/2008/TT-BTC, Decree No. 101/2011/ND-CP and Circular 160/2009/TT-BTC. 
From 2006 to 2011, there are three sub-periods of tax policy on dividends and capital gains in Vietnam. From January 2006 to December 2008, individual investors' dividends and capital gains were exempt from income tax while Vietnamese institutional investors' capital gains were charged at the rate of $28 \%$ and foreign institutional investors' capital gains were taxed at $1 \%$ of selling price. In the second period, dividends and capital gains of individual investors were exempt from income tax from to January 2009 to December 2009; then, they were charged $5 \%$ and $20 \%$ or $0.1 \%$ of selling price respectively from January 2010 to July 2011 . In addition, the tax rate for Vietnamese institutional investors' capital gains was reduced to $25 \%$. In the third sub-period, Vietnamese government reduced tax rates for individual investors' dividends and capital gains to $0 \%$ and by half respectively as a means to support individual investors in economic recession (Table 2).

\section{Literature Review and Hypothesis Development}

\subsection{Decisions of Paying or Not Paying Dividends}

Fama and French (2001) examining the phenomenon of disappearing dividends of listed firms on NYSE, AMEX, and NASDAQ from 1978 to 1999 find that there are two reasons for the decline in the proportion of paying firms, namely, changing firm characteristics and lower propensity to pay. The former includes profitability, firm size and investment opportunities. Grullon and Michaely (2002) make a contribution to explain "disappearing dividends puzzle" with the substitution of share repurchases for dividends. Moreover, propensity to pay dividend is also explained by catering incentives (Baker \& Wurgler, 2004). Due to the availability of information in Vietnamese stock market, this study only investigates the effect of firm characteristics on paying behavior. Return on assets, log of sales revenue are used as proxies for profitability and firm size while asset growth and market-to-book ratio are employed to measure investment opportunities. In line with Fama and French (2001), we develop the following hypotheses:

H1a: Return on assets is positively related to likelihood of paying dividends.

H1b: Sales revenue is positively related to likelihood of paying dividends.

H1c: Asset growth is negatively related to likelihood of paying dividends.

H1d: Market-to-book ratio is negatively related to likelihood of paying dividends.

In addition, Grullon, Michaely, and Swaminathan (2002) argue that younger firms which have more investment opportunities but lower profitability have more probability of paying dividends than older ones. The former prefer retention of earnings to distribution of earnings because their savings of transaction costs exceed agency costs. DeAngelo et al. (2006) test the life cycle hypothesis with listed firms in U.S. market and find that the earned/contributed capital mix is positively correlated to the probability of dividend payment. Denis and Osobov (2008) investigate the probability of paying dividends in developed markets and show supporting evidence for the impact of profitability, firm size, investment opportunities and earned/contributed capital mix on decisions of paying or not paying dividends. Therefore, earned/contributed capital mix is hypothesized to have positive relationship with probability to pay dividends.

H1e: Earned/contributed capital mix is positively related to likelihood of paying dividends.

Besides, Banerjee, Gatchev, and Spindt (2007) examine the relationship between stock liquidity and dividend policy with a sample of a sample of NYSE and AMEX listed firms from 1963 to 2003. Their findings show that after controlling other firm characteristics, firms with higher stock liquidity are less likely to pay dividends. Bartov and Bodnar (1996) posit that stock liquidity is a potential proxy for the degree of information asymmetry since investors buy stocks with less information asymmetry more than those with higher level of information asymmetry. This study uses annual share turnover to measure stock liquidity and hypothesizes that there is a negative relationship between annual share turnover and probability of dividend payment.

H1f: Annual share turnover is negatively related to likelihood of paying dividends.

Moreover, Jensen and Meckling (1976) posit that there is agency problem between shareholders and managers. Managers tend to use free cash flows to finance unprofitable projects and hence dividends are a means to reduce agency problem (Rozeff, 1982). When agency problem is more serious, firms are more likely to pay dividends. This study employs insider ownership to investigate the impact of agency problem on paying decisions. Lower insider ownership implies higher separation between ownership and firm management which results in higher agency costs. Therefore, it is hypothesized that there is a negative relationship between insider ownership and dividend payment.

H1g: Insider ownership is negatively related to likelihood of paying dividends.

According to Chen, Jian, and Xu (2009), state-related shareholders need more cash to finance other financially 
constrained SOEs or public projects. Hence, state-controlled firms tend to have higher probability to pay dividends. We use a dummy variable assigned one for state-controlled firms and hypothesize that state control have a positive impact on paying decisions.

H1h: State control is positively related to likelihood of paying dividends.

\subsection{Decisions of Dividend Levels}

Transaction cost theory, residual theory, and pecking order theory have the same argument that firms prefer internal financing to external financing. Firstly, if transaction costs of issuing debt or equity are significant, firms with higher transaction costs will retain more earnings to finance business activities and hence pay lower dividends. Secondly, according to residual theory, firms will pay dividends only if they do not have profitable investment opportunities (Ghosh \& Woolridge, 1989). Thirdly, pecking order argument developed by Myers and Majluf (1984) states that firms prioritize sources of financing from internal funds to equity due to information asymmetry between managers and outside investors. Therefore, when firms have more investment opportunities, they tend to retained more earnings and payless dividends. Higgins (1972); Rozeff (1982) find significant negative impacts of investment expenditures on dividend levels in US stock markets. The extant literature shows that asset growth and market-to-book value ratio are commonly used proxies for current and future investment opportunities (Fama \& French, 2001). Thus, this study hypothesizes that both market-to-book ratio and asset growth have negative effects on dividend magnitide.

H2a: Asset growth is negatively related to dividend level.

$\mathrm{H} 2 \mathrm{~b}$ : Market-to-book ratio is negatively related to dividend level.

Moreover, when firms are more likely to use internal financing, firms with higher leverage tend to pay lower dividends. G. R. Jensen, Solberg, and Zorn (1992) find negative impact of firm leverage on dividend policy. Therefore, leverage is hypothesized to have negative relationship with dividend level.

$\mathrm{H} 2 \mathrm{c}$ : Leverage is negatively related to dividend level.

In stock markets, insiders have more information on firms' profitability than outside investors (Miller \& Rock, 1985). Bhattacharya (1979) argues that cash dividends are a signal of firms' future performance and firms paying higher levels of dividends are considered to be more profitable in the future. It implies that when information asymmetry is reduced, firms pay lower levels of dividends. This study employs stock liquidity measured by annual share turnover as a proxy for information asymmetry. In line with Bartov and Bodnar (1996), stock liquidity is hypothesized to have negative relationship on dividend level.

$\mathrm{H} 2 \mathrm{~d}$ : Annual share turnover is negatively related to dividend level.

Based on the argument of agency problem, Rozeff (1982) develops free cash flow hypothesis stating that dividend payment is a device to mitigate excessive funds which managers can use to invest in negative net present value projects. Holder et al. (1998) initially employ free cash flow to test agency theory with the sample of 477 firms listed in US stock market between 1983 and 1990. Their research findings show firms with higher free cash flows pay lower levels of dividends. Therefore, this study hypothesizes that there is a positive relationship between free cash flow and dividend payout ratio.

H2e: Free cash flow is positively related to dividend level.

In addition, Rozeff (1982) posit that insider ownership is a measure of agency costs. Lower insider ownership indicates higher agency costs; therefore, outsiders who hold larger percentage of shares will demand higher dividends to reduce agency costs. Holder et al. (1998); Rozeff (1982) find empirical evidence supporting the negative relationship between the percentage of insider ownership and dividend payments.

H2f: Insider ownership is negatively related to dividend level.

Chen et al. (2009) argue that state-controlled firms pay higher levels of dividends than non-state-controlled firms since they need more funds to finance other financially constrained SOEs or public projects. In addition, Gugler (2003) argue that the "double principal-agent problem" arises in state-controlled firms. These firms are operated by managers who are appointed by politicians. Politicians are elected by citizens who are real owners of state-controlled firms. Consequently, they pay higher dividends to mitigate agency costs. Wei, Zhang, and Xiao (2004) also find the positive effect of state control on dividend payout ratio.

$\mathrm{H} 2 \mathrm{~g}$ : State control is positively related to dividend level. 


\section{Data}

\subsection{Sample Selection}

In the period from 2006 to 2011, there are 2,131 non-financial observations in both Ho Chi Minh Stock Exchange (HSX) and Ha Noi Stock Exchange (HNX). However, to improve the accuracy of research findings, observations which are subject to one of the following criteria are eliminated from the research data:

- Observations belonging to the period from 2000 to 2005 since the number of listed firms was extremely limited and the information of dividend payment is not available;

- Observations of the listing year;

- Observations with missing or incomplete information;

- Observations with dividend payout ratios greater than one as outliers (Grullon \& Michaely, 2002);

The final research sample includes 1339 observations including 284 non-payers and 1055 payers.

Table 3. Distribution of non-financial observations in Vietnamese stock market and the research sample

\begin{tabular}{lcccccc}
\hline \multirow{2}{*}{ Panel A - Year } & \multicolumn{3}{c}{ Firms in the population } & \multicolumn{3}{c}{ Firms in the sample } \\
& HSX & HNX & Total & HSX & HNX & Total \\
\hline 2006 & 77 & 86 & 163 & 20 & 8 & 28 \\
2007 & 101 & 114 & 215 & 71 & 75 & 146 \\
2008 & 126 & 168 & 294 & 88 & 98 & 186 \\
2009 & 159 & 226 & 385 & 112 & 136 & 248 \\
2010 & 211 & 306 & 517 & 141 & 173 & 314 \\
2011 & 234 & 323 & 557 & 182 & 235 & 417 \\
Total & 908 & 1223 & 2131 & 614 & 725 & 1339 \\
\hline Panel B - Industry sector & Firms in the population & & & Firms in the sample & \\
& HSX & HNX & Total & HSX & HNX & Total \\
\hline Industrials & 387 & 806 & 1193 & 246 & 468 & 714 \\
Consumer goods & 242 & 110 & 352 & 176 & 73 & 249 \\
Basic materials & 123 & 98 & 221 & 70 & 51 & 121 \\
Consumer services & 48 & 91 & 139 & 28 & 60 & 88 \\
Oil and Gas & 17 & 37 & 54 & 13 & 24 & 37 \\
Health care & 34 & 21 & 55 & 25 & 10 & 35 \\
Communication & 7 & 7 & 14 & 5 & 6 & 11 \\
Utilities & 60 & 27 & 87 & 42 & 19 & 61 \\
Technology & 13 & 34 & 47 & 9 & 14 & 23 \\
Total & 931 & 1231 & 2162 & 614 & 725 & 1339 \\
\hline
\end{tabular}

In Table 3, Panel A shows distribution of non-financial observations in the population and the research sample by year. In the first booming year of 2006, 163 non-financial firms are listed in Ho Chi Minh City Stock Exchange and Hanoi Stock Exchange; however, there are only 28 firms in the research sample due to the elimination of 132 newly listed firms and 3 firms with missing or incomplete information. The number of observations in the sample increases from 146 to 417 over the period from 2007 to 2011. Panel B illustrates the number of non-financial observations in each industry sector in accordance with the Industry Classification Benchmark. About 55\% non-financial firms in the population and the sample are from the Industrials sector. It is followed by Consumer goods $(16 \%-19 \%)$, Basic materials $(9 \%-10 \%)$, Consumer services $(6 \%-7 \%)$, Utilities $(4 \%-5 \%)$, Health care (3\%), Oil and Gas (2\%) and Communication (1\%).

\subsection{Variable Definitions}

\subsubsection{Dependent Variables}

Dependent variable to investigate decisions of paying or not paying dividends is a binary variable which is one if firms pay dividends and zero otherwise.

Dividend levels are measured by dividend payout ratio (DPR) and dividend yield (DY). The former is measured by the proportion of earnings paid to shareholders as dividends and the latter is calculated by the ratio of annual dividend per share to stock price at the end of each year. Their definitions illustrate that dividend payout ratio 
contains internal characteristics of firms (McManus, Ap Gwilym, \& Thomas, 2004) whilst dividend yields tend to be affected by external factors which are reflected by stock prices (Stevens \& Jose, 1992). In addition, dividend payout ratio illustrates information on firms' financing behavior whilst dividend yield implies information on rate of return of investors.

4.2.2 Exploratory Variables

Table 4. Definitions of exploratory variables

\begin{tabular}{llc}
\hline Variables & Definitions & Expected signs \\
\hline Return on assets (ROA) & Net income divided by total assets & + \\
Firm size (SIZ) & Log of sales revenue & + \\
Asset growth (AGR) & Ratio of current year's change in total assets & - \\
Market-to-book ratio (MTB) & Market value of assets divided by total assets at the end of each year & - \\
Leverage (LEV) & Ratio of total debt to total assets & - \\
Earned/contributed capital mix (ECC) & Retained earnings to equity & - \\
Annual share turnover (AST) & Ratio of annual total trading volume to average number of outstanding & + \\
& shares & (Operating income + depreciation - taxes - interest expenses - preferred \\
Free cash flow (FCF) & dividends - ordinary dividends)/total assets & - \\
& Proportion of shares held by insiders & + \\
Insider ownership (INS) & 1 for the state-controlled firms which have more than 50 percent of \\
State control (STA) & common shares owned by State or its agencies & + \\
\end{tabular}

Return on assets (ROA) is net income divided by total assets. Firm size (SIZ) is log of sales revenue.

Asset growth (AGR) is ratio of current year's change in total assets and market-to-book ratio (MTB) is calculated as market value of assets divided by total assets at the end of each year (Fama \& French, 2001; Grullon \& Michaely, 2002). Leverage is defined as ratio of total debt to total assets.

Earned/contributed capital mix (ECC) is measured by ratio of retained earnings to equity (DeAngelo et al., 2006; Denis \& Osobov, 2008).

Annual share turnover (AST) is measured by ratio of annual total trading volume to average number of outstanding shares. Although trading volume is affected by information events (Beaver, 1968), the number of information days is relatively small compared with the number of trading days. Therefore, the errors-in-variables problem is insignificant (Bartov \& Bodnar, 1996).

Free cash flow (FCF) is calculated as operating net income before depreciation minus corporate income tax, interest expenses, and cash dividends deflated by total assets. Although the extant literature shows several measures of free cash flow, this study uses the definition of free cash flow suggested by Lang, Stulz, and Walkling (1991) since it indicates the actual free cash flow which is available to managers (Wang, 2010).

Insider ownership (INS) is measured by proportion of shares held by insiders (Holder et al., 1998; Rozeff, 1982). State control (STA) is represented by a dummy variable which is assigned "one" if firms are state-controlled, "zero" otherwise (Gugler, 2003; Wei et al., 2004). State-controlled firms are defined as firms with more than 50 percent of total outstanding shares held by State or its agencies.

In addition, during the research period, there are fluctuations in stock prices and changes in tax policy. The percentage of listed firms varies by industry sector. Therefore, in order to control effects of time and industry sector on dividend policy, this study uses dummy variables for years and industry sectors in two regression steps.

Relevant information to calculate all variables except insider ownership is from the database supplied by Tan Viet Securities Company (www.tvsi.com.vn) and cross-checked with Stockbiz database (www.stockbiz.vn). Tan Viet and Stockbiz are leading database suppliers in Vietnam. Insider ownership is collected from annual reports by hand. 


\subsection{Descriptive Statistics}

Table 5. Counts and percentage of firms in various dividend groups

\begin{tabular}{lcccccc}
\hline & 2006 & 2007 & 2008 & 2009 & 2010 & 2011 \\
\hline Counts of the sample & & & & & & \\
All firms & 28 & 146 & 186 & 248 & 314 & 417 \\
Non-payers & 4 & 17 & 21 & 43 & 59 & 140 \\
Payers & 24 & 129 & 165 & 205 & 255 & 277 \\
New lists & 28 & 118 & 41 & 59 & 67 & 109 \\
State-controlled & 4 & 52 & 65 & 89 & 108 & 137 \\
Percentage in all firms (\%) & & & & & & \\
Non-payers & 14.3 & 11.6 & 11.3 & 17.3 & 18.8 & 33.6 \\
Payers & 85.7 & 88.4 & 88.7 & 82.7 & 81.2 & 66.4 \\
New lists & 100.0 & 80.8 & 22.0 & 23.8 & 21.3 & 26.1 \\
State-controlled & 14.3 & 35.6 & 34.9 & 35.9 & 34.4 & 32.9 \\
Percentage in new lists (\%) & & & & & & \\
Payers & 85.7 & 88.1 & 87.8 & 76.3 & 88.1 & 64.2 \\
Non-payers & 14.3 & 11.9 & 12.2 & 23.7 & 11.9 & 35.8 \\
Percentage in state-controlled firms (\%) & & & & & & 80.3 \\
Payers & 100.0 & 96.2 & 95.4 & 88.8 & 90.7 & 19.7 \\
Non-payers & 0.0 & 3.8 & 4.6 & 11.2 & 9.3 & \\
\hline
\end{tabular}

Table 5 illustrates the number and the proportion of observations in different dividend groups. In line with many emerging markets, Vietnamese stock market experiences high percentage of paying firms in the research period. The proportion of payers increases slightly in the first three years from $85.7 \%$ (2006) to $88.7 \%$ (2008) and declines to $81.2 \%$ (2010). In 2011, due to more severe recession in Vietnamese economy, listed firms have lowest profitability in the research period with the average return on assets of $6.2 \%$. Therefore, firms are less likely to pay dividends and payers account for $66.4 \%$ of sampled firms in this year. In addition, new lists which are defined as observations of the second year of listing constitute over $20 \%$ of firms in the sample each year. Contrary to findings of Fama and French (2001) in the U.S. market, the yearly proportion of new lists paying dividends is equivalent to that of paying firms in the research sample. Moreover, state-controlled firms comprise approximately one-third of sampled firms. The percentage of payers in state-controlled firms is higher than in the full sample over the period from 2006 to 2011. This indicates that state-controlled firms are more likely to pay dividends than private firms.

Table 6. Counts and percentage of non-payers and payers by industry sector

\begin{tabular}{lcccc}
\hline & \multicolumn{2}{c}{ Non-payers $(\mathrm{N}=284)$} & \multicolumn{2}{c}{ Payers (N=1055) } \\
& Counts & Percentage (\%) & Counts & Percentage (\%) \\
\hline Industrials & 161 & 22.5 & 553 & 77.5 \\
Consumer goods & 46 & 18.5 & 203 & 81.5 \\
Basic materials & 28 & 23.1 & 93 & 76.9 \\
Consumer services & 16 & 18.2 & 72 & 81.8 \\
Oil and Gas & 4 & 10.8 & 33 & 89.2 \\
Health care & 4 & 11.4 & 31 & 88.6 \\
Communication & 6 & 54.5 & 5 & 45.5 \\
Utilities & 9 & 14.8 & 52 & 85.2 \\
Technology & 10 & 43.5 & 13 & 56.5 \\
\hline
\end{tabular}

Table 6 presents counts and proportion of non-payers and payers by industry sector. Percentage of payers in the four largest industry sectors including Industrials, Consumer goods, Basic materials and Consumer services ranges from $77 \%$ to $82 \%$. Other industries with higher proportion of paying firms (Oil and Gas, Health care) or lower proportion of paying firms (Communication, Technology) only comprise about $12.5 \%$ of firms in the research data. This implies that there is no considerable impact of industry sectors on decisions of paying or not 
paying dividends.

Table 7. Summary statistics of research variables of dividend paying decisions

\begin{tabular}{lcccccc}
\hline & \multicolumn{3}{c}{ Non-payers $(\mathrm{N}=284)$} & \multicolumn{3}{c}{ Payers (N=1055) } \\
& Median & Mean & Std. dev. & Median & Mean & Std. dev. \\
\hline DPR & 0.00 & 0.00 & 0.00 & 0.52 & 0.52 & 0.21 \\
DY & 0.00 & 0.00 & 0.00 & 0.07 & 0.09 & 0.06 \\
ROA & 0.01 & 0.02 & 0.07 & 0.08 & 0.09 & 0.07 \\
SIZ & 26.20 & 26.33 & 1.40 & 26.78 & 26.76 & 1.36 \\
AGR & 0.07 & 0.18 & 0.51 & 0.18 & 0.27 & 0.40 \\
MTB & 0.91 & 1.02 & 0.55 & 1.02 & 1.28 & 0.90 \\
ECC & 0.04 & -0.02 & 0.42 & 0.14 & 0.15 & 0.10 \\
AST & 0.69 & 1.43 & 3.05 & 0.71 & 1.15 & 1.30 \\
INS & 0.07 & 0.13 & 0.15 & 0.03 & 0.08 & 0.11 \\
STA & 0.00 & 0.18 & 0.39 & 0.00 & 0.38 & 0.49 \\
\hline
\end{tabular}

DPR is dividend payout ratio. DY is dividend yield. ROA is return on assets. SIZ is log of sales revenue. AGR is ratio of current year's change in total assets. MTB is market value of assets divided by total assets at the end of each year. ECC is ratio of retained earnings to equity. AST is ratio of annual total trading volume to average number of outstanding shares. INS is proportion of shares held by insiders. STA is dummy variable assigned one for the state-controlled firms which have more than 50 percent of common shares owned by State or its agencies, zero otherwise.

Table 7 shows descriptive statistics of research variables in two groups of observations including non-payers and payers. It is clear that on average, paying firms distribute more than $50 \%$ of earnings as dividends and their dividend yield is $9 \%$. They have much higher average profitability, retained earnings to equity and larger size than zero dividend firms. Average asset growth and market-to-book ratio of payers are slightly higher than those of non-payers but with large standard deviations. In addition, average annual share turnover and insider ownership of positive dividend observations are lower than those of zero dividend observations. The descriptive statistic of state control dummy variable indicates that state-controlled firms are more likely to pay dividends in the period between 2009 and 2011.

Table 8. Summary statistics of paying firms' research variables grouped by into quartiles by dividend payout ratio

\begin{tabular}{lcccccccc}
\hline & \multicolumn{2}{c}{ Q1 } & \multicolumn{2}{c}{ Q2 } & \multicolumn{2}{c}{ Q3 } & \multicolumn{2}{c}{ Q4 } \\
& Mean & Std. dev. & Mean & Std. dev. & Mean & Std. dev. & Mean & Std. dev. \\
\hline DPR & 0.26 & 0.08 & 0.44 & 0.04 & 0.59 & 0.04 & 0.80 & 0.08 \\
DY & 0.06 & 0.04 & 0.08 & 0.05 & 0.10 & 0.07 & 0.11 & 0.07 \\
AGR & 0.34 & 0.29 & 0.29 & 0.52 & 0.22 & 0.34 & 0.22 & 0.41 \\
MTB & 1.49 & 1.26 & 1.32 & 0.72 & 1.23 & 0.74 & 1.10 & 0.71 \\
LEV & 0.51 & 0.21 & 0.49 & 0.23 & 0.49 & 0.22 & 0.45 & 0.24 \\
AST & 1.30 & 1.52 & 1.03 & 1.00 & 1.09 & 1.22 & 1.16 & 1.40 \\
FCF & 0.11 & 0.09 & 0.07 & 0.09 & 0.06 & 0.12 & 0.02 & 0.05 \\
INS & 0.09 & 0.13 & 0.07 & 0.11 & 0.07 & 0.09 & 0.07 & 0.10 \\
STA & 0.35 & 0.48 & 0.41 & 0.49 & 0.42 & 0.49 & 0.36 & 0.48 \\
\hline
\end{tabular}

DPR is dividend payout ratio. DY is dividend yield. AGR is ratio of current year's change in total assets. MTB is market value of assets divided by total assets at the end of each year. LEV is ratio of total debt to total assets. AST is ratio of annual total trading volume to average number of outstanding shares. FCF is (operating income + depreciation - taxes - interest expenses - preferred dividends - ordinary dividends) divided by total assets. INS is proportion of shares held by insiders. STA is dummy variable assigned one for the state-controlled firms which have more than 50 percent of common shares owned by State or its agencies, zero otherwise.

In Table 8, research variables of payers are grouped into quartiles by payout ratio. From the lowest to the highest quartile, means of dividend yield, asset growth, market-to-book, leverage and free cash flow tend to decrease considerably. Average annual share turnover and standard deviation in the first quartile are higher than in the second quartile; however, from the second quartile to the fourth quartile they increases slightly. Insider 
ownership mean is 0.09 in the lowest quartile and remain steady at 0.07 in the following quartiles. On average, market-to-book ratio decreases rapidly from the lowest quartile (1.49) to the highest quartile $(0.22)$; nevertheless, it has high levels of standard deviation.

\section{Method}

On the one hand, from econometric perspective, the research sample is a censored sample in which dividends are continuous to the right of zero. Using OLS regressions both for the full sample of non-payers and payers or the subsample of payers leads to biased results due to selection problem. In this case, tobit and Heckman two-step regressions are suggested instead (Wooldridge, 2010). On the other hand, dividend policy includes two steps of making decisions. Firstly, firms decided to pay or not to pay dividends. Secondly, if firms decide to pay dividends, they continue to decide the magnitude of dividends. Therefore, Heckman two-step selection approach is more appropriate to investigate dividend policy.

In the first step, a probit regression model is used to estimate the probability of dividend payments as follows:

$$
\mathrm{PPD}_{\mathrm{i}}=\left\{\begin{array}{l}
1 \text { if } P P D_{i}^{*}>0 \\
0 \text { if } P P D_{i}^{*} \leq 0
\end{array}\right.
$$

Where $\mathrm{PPD}_{\mathrm{i}}$ is the observable dependent variable which takes one if $\mathrm{PPD}^{*}>0$ and zero otherwise.

PPD* is the latent variable: $P P D_{i}{ }^{*}=\alpha+\beta X_{l i}+u_{i} ; \mathrm{u}_{\mathrm{i}} \sim \mathrm{N}\left(0, \sigma^{2}\right)$

$X_{\mathrm{it}}$ is the column vector of explanatory variables of firm i. The vector contains ROA, SIZ, AGR, MTB, ECC, AST, INS and STA.

ui is the residual term of firm $i$.

The first step probit regression also generates the inverse Mill's ratio (IMR) which is denoted as $\lambda$ and measured by the following formula:

$$
\lambda_{i}=\varphi\left(X_{1 i} \beta\right) / \Phi\left(X_{1 i} \beta\right)
$$

Where $\varphi$ is the standard normal density function and $\Phi$ is the standard normal cumulative distribution function.

In the second step, pooled OLS regression model is applied to estimate relationships between dividend payout ratio and its determinants by regressing payout ratio on $\mathrm{X}_{2 \mathrm{i}}$ and $\lambda_{\mathrm{i}}$. Where $\mathrm{X}_{2 \mathrm{i}}$ is the explanatory variables of firm i. The vector $\mathrm{X}_{2 \mathrm{i}}$ contains AGR, MTB, LEV, AST, FCF, INS and STA. If the IMR is significant, there is a selection bias which is fixed by the two-step selection approach.

\section{Findings}

Table 9. Results of Heckman's two step regression with year and industry dummies Panel A. The first step

\begin{tabular}{cccc}
\hline $\begin{array}{c}\text { Explanatory } \\
\text { variables }\end{array}$ & $\begin{array}{c}\text { Expected } \\
\text { sign }\end{array}$ & Coefficients & z-statistics \\
\hline Intercept & & $-4.0505^{* * *}$ & -3.63 \\
ROA & + & $12.9328^{* * *}$ & 9.38 \\
SIZ & + & $0.1810^{* * *}$ & 4.74 \\
AGR & - & 0.0586 & 0.55 \\
MTB & - & $-0.3103^{* * *}$ & -2.98 \\
ECC & + & $1.5398^{* * *}$ & 3.09 \\
AST & - & $-0.0792^{* * *}$ & -2.7 \\
INS & - & $-1.8743^{* * *}$ & -4.35 \\
STA & + & $0.2296^{*}$ & 1.92 \\
\hline
\end{tabular}


Panel B. The second step

\begin{tabular}{|c|c|c|c|c|c|}
\hline \multirow{2}{*}{$\begin{array}{c}\text { Explanatory } \\
\text { variables }\end{array}$} & \multirow{2}{*}{ Expected sign } & \multicolumn{2}{|c|}{ DPR } & \multicolumn{2}{|c|}{ DY } \\
\hline & & Coefficients & z-statistics & Coefficients & z-statistics \\
\hline Intercept & & $0.6407 * * *$ & 3.64 & $0.0437 * * *$ & 2.6 \\
\hline AGR & - & -0.0143 & -0.37 & $-0.0079 * *$ & -2.09 \\
\hline MTB & - & -0.0307 & -1.36 & $-0.011 * * *$ & -5.22 \\
\hline LEV & - & $-0.3455 * * *$ & -4.65 & $0.0173^{* *}$ & 2.36 \\
\hline AST & - & -0.019 & -1.51 & 0.0005 & 0.41 \\
\hline FCF & + & $-0.5354 * * *$ & -2.94 & -0.0265 & -1.49 \\
\hline INS & - & $-0.3562 * *$ & -2.29 & 0.0004 & 0.03 \\
\hline STA & + & 0.0328 & 0.88 & -0.0017 & -0.48 \\
\hline \multicolumn{2}{|c|}{ Wald $\chi^{2}$} & \multicolumn{2}{|c|}{$54.95 * * *$} & \multicolumn{2}{|c|}{$965.04 * * *$} \\
\hline \multicolumn{2}{|c|}{ Lamda } & \multicolumn{2}{|c|}{$0.5390 * * *$} & \multicolumn{2}{|c|}{$-0.0335^{* * *}$} \\
\hline \multicolumn{2}{|c|}{ Number of observations } & \multicolumn{4}{|c|}{1339} \\
\hline \multicolumn{2}{|c|}{ Censored observations } & \multicolumn{4}{|c|}{284} \\
\hline \multicolumn{2}{|c|}{ Uncensored observations } & \multicolumn{4}{|c|}{1055} \\
\hline
\end{tabular}

In the first step, dependent variable is a binary variable which takes one if firms pay dividends, zero otherwise. In the second step, dependent variables are dividend payout ratio (DPR) and dividend yield (DY). ROA is return on assets. SIZ is log of sales revenue. AGR is ratio of the current year's change in total assets. MTB is market value of assets divided by total assets at the end of each year. LEV is ratio of total debt to total assets. ECC is ratio of retained earnings to equity. AST is ratio of annual total trading volume to average number of outstanding shares. FCF is (operating income + depreciation - taxes - interest expenses - preferred dividends - ordinary dividends) divided by total assets. INS is proportion of shares held by insiders. STA is dummy variable assigned one for the state-controlled firms which have more than 50 percent of common shares owned by State or its agencies, zero otherwise. *** Significant at the $1 \%$ level, ** Significant at the $5 \%$ level, * Significant at $10 \%$ level.

In Table 9, Panel A presents results of Heckman's first step probit regression with both year and industry dummy variables. In consistent with Denis and Osobov (2008); Fama and French (2001), market-to-book ratio, a measure of investment opportunities, is negatively related to probability of paying dividends while profitability and firm size have significantly positive impacts on probability of dividend payments. Firms prefer internal financing to external financing; therefore, they are less likely to pay dividends when they have more investment opportunities. In addition, firms with higher profitability are more likely to have residual cash flows after financing their investment projects; therefore, they are more likely to distribute dividends. Moreover, larger firms can raise external funds to finance investment opportunities more easily in capital markets as they are well-establish and have good reputation (Chang \& Rhee, 1990; Holder et al., 1998). This implies that larger firms incur lower transaction costs of external financing and are more likely to pay dividends.

Earned/contributed capital mix is positively associated with the probability to pay dividends at $1 \%$ of significance. In line with DeAngelo et al. (2006); Grullon et al. (2002), more mature firms with higher earned/contributed capital mix are more likely to have residual cash flows hence they have higher probability of dividend payment. The significantly negative relationship between annual share turnover and payout ratio can be explained by signaling mechanism. Higher stock liquidity indicates that firms experience lower levels of information asymmetry between outside investors and insiders. Consequently, they have lower propensity to pay dividends as a signal of firm quality. Besides, the negative correlation between insider retention and the likelihood of dividend payments implies that firms use dividends as a device to reduce conflicts of interest between managers and shareholders. If insider retention is lower, the separation of ownership and control in firms is higher and managers tend to use free cash flows to maximize their own interest instead of shareholders' wealth (Jensen \& Meckling, 1976). Therefore, firms are more likely to become payers in order to reduce excessive funds which are available to managers. State-controlled firms have higher probability to distribute dividends since they need funds to support other SOEs which are financially constrained and finance public projects for political goals (Chen et al., 2009).

Panel B illustrates findings of Heckman's second step regression with both year and industry dummy variables. Two proxies for investment opportunities including asset growth and market-to-book ratio are negatively related to dividend yield at significant levels of $5 \%$ and $1 \%$ respectively. If firms have more investment opportunities, they retain more earnings for internal financing and their stocks are valued at higher prices due to investors' expectation on their future prospects. As a result, firms with more investment opportunities tend to have lower dividend yields. In addition, leverage is negatively related to payout ratio at the significant level of $1 \%$ while it has a positive 
relationship with dividend yield at the significant level of 5\%. The former implies that firms with higher leverage need more retained earnings for internal financing and hence, they distribute a lower proportion of earnings as dividends. The latter is explained that firms with higher debt ratios are exposed to higher risk for bankruptcy; therefore, investors expect higher returns for their stocks and value them at lower prices which lead to higher levels of dividend yields.

Remarkably, contrary to free cash flow hypothesis, free cash flows to total assets ratio is inversely related to payout ratio at $1 \%$ of significance. This can be explained that when having more business opportunities, firms tend to hold more free cash flows to finance their business activities and pay lower levels of dividends. It is in line with the negative relationship between investment opportunities and dividend yield. Moreover, in consistent with Holder et al. (1998); Rozeff (1982), insider ownership has a negative impact on dividend payout ratio at the significant level of $5 \%$. When insiders hold lower percentage of shares, outsiders require more dividends to mitigate agency problem. Thus, firms distribute lower dividends.

\section{Robustness Check}

Table 10. Robustness check of the second step by OLS regression with year and industry dummies

\begin{tabular}{|c|c|c|c|c|c|}
\hline \multirow{2}{*}{ Explanatory variables } & \multirow{2}{*}{ Expected sign } & \multicolumn{2}{|c|}{ DPR } & \multicolumn{2}{|c|}{ DY } \\
\hline & & Coefficients & t-statistics & Coefficients & $\mathrm{t}$-statistics \\
\hline Intercept & & $0.6964 * * *$ & 10.38 & $0.04 * *$ & 2.46 \\
\hline AGR & - & $-0.0317 * *$ & -2.09 & $-0.0067^{*}$ & -1.83 \\
\hline MTB & - & $-0.0277 * * *$ & -3.33 & $-0.0112 * * *$ & -5.58 \\
\hline LEV & - & $-0.2054 * * *$ & -7.15 & 0.0081 & 1.16 \\
\hline AST & - & -0.0012 & -0.25 & -0.0007 & -0.56 \\
\hline FCF & + & $-0.8647 * * *$ & -12.6 & -0.0048 & -0.29 \\
\hline INS & - & $-0.1427 * *$ & -2.44 & -0.0136 & -0.96 \\
\hline STA & + & -0.002 & -0.14 & 0.0006 & 0.18 \\
\hline \multicolumn{2}{|c|}{ Adj. R-squared } & \multicolumn{2}{|c|}{0.2301} & \multicolumn{2}{|c|}{0.4898} \\
\hline \multicolumn{2}{|c|}{$\mathrm{F}(20,1034)$} & \multicolumn{2}{|c|}{$16.75^{* * *}$} & \multicolumn{2}{|c|}{$51.58 * * *$} \\
\hline \multicolumn{2}{|c|}{ Number of observations } & \multicolumn{2}{|c|}{1055} & \multicolumn{2}{|c|}{1055} \\
\hline
\end{tabular}

Dependent variables are dividend payout ratio (DPR) and dividend yield (DY). AGR is ratio of current year's change in total assets. MTB is market value of assets divided by total assets at the end of each year. LEV is ratio of total debt to total assets. AST is ratio of annual total trading volume to average number of outstanding shares. FCF is (operating income + depreciation - taxes - interest expenses - preferred dividends - ordinary dividends) divided by total assets. INS is proportion of shares held by insiders. STA is dummy variable assigned one for the state-controlled firms which have more than 50 percent of common shares owned by State or its agencies, zero otherwise. *** Significant at the $1 \%$ level, ** Significant at the $5 \%$ level, * Significant at $10 \%$ level.

Table 10 shows results of OLS regression with year and industry dummies for the subsample of dividend payers. The findings of this robustness check confirm the impact of investment opportunities and agency problem on dividend levels. However, compared with Heckman's second step regression, OLS regression has differences in significant levels of coefficients due to the presence of selection bias which is indicated by significant IMRs. Asset growth and market-to-book ratio are negatively related to dividend payout ratio at $5 \%$ and $1 \%$ of significance. Although, asset growth and leverage have lower explanatory power for dividend yield, these findings also confirm supporting evidence for efficient market hypothesis which states that stock prices reflect all available information in stock markets.

\section{Conclusion}

During the period from 2006 to 2011, there are about $80 \%$ of listed firms paying dividends and their average payout ratio and dividend yield are over 50\% and $9 \%$ respectively. This study investigates dividend policy with two steps including decisions of paying dividends and decisions of dividend levels. Heckman's two-step regression approach is applied to fix the selection bias caused by censored research data.

Research findings show that while dividend payment is not affected by new listings and industry-specific factors, it is determined by firm characteristics. The first step regression results are consistent with Fama and French (2001) in terms of profitability, firm size and investment opportunities. In addition, more mature firms with higher retained earnings to equity ratio have higher probability of paying dividends. Moreover, in line with Banerjee et al. (2007) and Rozeff (1982), firms with higher stock liquidity and insider ownership have lower 
likelihood of paying dividends respectively. State-controlled firms are more likely to pay dividends than non-state-controlled firms since they need funds to finance other financially constrained SOEs or public projects (Chen et al., 2009). The second step regression illustrates that firms with higher asset growth and market-to-book ratio have lower dividend yields. Leverage has negative and positive impacts on payout ratio and dividend yield respectively. These findings show supporting evidence for the efficient market hypothesis. Besides, contrary to free cash flow hypothesis, free cash flows to total assets ratio is negatively related to payout ratio. It can be explained by firms' investment opportunities. Moreover, insider ownership has a negative impact on dividend payout ratio.

However, this study fails to investigate the relationship between changes in tax policy and dividend policy comprehensively. From 2006 to 2011, there are changes in income tax rates on dividends and capital gains. Further studies can examine the effect of income tax policy on dividend policy or ex-dividend behavior of stock prices.

\section{References}

Abor, J., \& Fiador, V. (2013). Does corporate governance explain dividend policy in Sub-Saharan Africa? International Journal of Law \& Management, 55(3), 201-225. http://dx.doi.org/10.1108/17542431311327637

Baker, M., \& Wurgler, J. (2004). A catering theory of dividends. Journal of Finance, 59(3), 1125-1165. http://dx.doi.org/10.1111/j.1540-6261.2004.00658.x

Banerjee, S., Gatchev, V. A., \& Spindt, P. A. (2007). Stock market liquidity and firm dividend policy. Journal of Financial and Quantitative Analysis, 42(2), 369-398. http://dx.doi.org/10.1017/S0022109000003318

Bartov, E., \& Bodnar, G. M. (1996). Alternative accounting methods, information asymmetry and liquidity: Theory and evidence. Accounting Review, 71(3), 397-418.

Beaver, W. H. (1968). The information content of annual earnings announcements. Journal of Accounting Research, 6(3), 67-92. http://dx.doi.org/10.2307/2490070

Bhattacharya, S. (1979). Imperfect information, dividend policy, and "the bird in the hand" fallacy. Bell Journal of Economics, 10(1), 259-270. http://dx.doi.org/10.2307/3003330

Chang, R. P., \& Rhee, S. G. (1990). The impact of personal taxes on corporate dividend policy and capital structure decisions. The Journal of the Financial Management Association, 19(2), 21-31. $\mathrm{http}: / / \mathrm{dx}$.doi.org/10.2307/3665631

Chen, D., Jian, M., \& Xu, M. (2009). Dividends for tunneling in a regulated economy: The case of China. Pacific-Basin Finance Journal, 17(2), 209-223. http://dx.doi.org/10.1016/j.pacfin.2008.05.002

DeAngelo, H., DeAngelo, L., \& Stulz, R. M. (2006). Dividend policy and the earned/contributed capital mix: a test of the life-cycle theory. Journal of Financial Economics, 81(2), 227-254. http://dx.doi.org/10.1016/j.jfineco.2005.07.005

Denis, D. J., \& Osobov, I. (2008). Why do firms pay dividends? International evidence on the determinants of $\begin{array}{lllll}\text { dividend policy. Journal of Financial Economics, } & \text { 89(1), 62-82. }\end{array}$ http://dx.doi.org/10.1016/j.jfineco.2007.06.006

Fama, E. F., \& French, K. R. (2001). Disappearing dividends: Changing firm characteristics or lower propensity to pay? Journal of Financial Economics, 60(1), 3-43. http://dx.doi.org/10.1016/S0304-405X(01)00038-1

Fatemi, A., \& Bildik, R. (2012). Yes, dividends are disappearing: Worldwide evidence. Journal of Banking \& Finance, 36(3), 662-677. http://dx.doi.org/10.1016/j.jbankfin.2011.10.008

Ghosh, C., \& Woolridge, J. R. (1989). Stock-market reaction to growth-induced dividend cuts: Are investors myopic? Managerial \& Decision Economics, 10(1), 25-35. http://dx.doi.org/10.1002/mde.4090100104

Grullon, G., \& Michaely, R. (2002). Dividends, share repurchases, and the substitution hypothesis. The Journal of Finance, 57(4), 1649-1684. http://dx.doi.org/10.1111/1540-6261.00474

Grullon, G., Michaely, R., \& Swaminathan, B. (2002). Are dividend changes a sign of firm maturity? Journal of Business, 75(3), 387-424. http://dx.doi.org/10.1086/339889

Gugler, K. (2003). Corporate governance, dividend payout policy, and the interrelation between dividends, R\&D, and capital investment. Journal of Banking and Finance, 27(7), 1297-1321. http://dx.doi.org/10.1016/S0378-4266(02)00258-3 
Higgins, R. C. (1972). The corporate dividend-saving decision. Journal of Financial \& Quantitative Analysis, 7(2), 1527-1541. http://dx.doi.org/10.2307/2329932

Holder, M. E., Langrehr, F. W., \& Hexter, J. L. (1998). Dividend policy determinants: An investigation of the influences of stakeholder theory. The Journal of the Financial Management Association, 27(3), 73. http://dx.doi.org/10.2307/3666276

Jensen, G. R., Solberg, D. P., \& Zorn, T. S. (1992). Simultaneous determination of insider ownership, debt, and dividend policies. Journal of Financial \& Quantitative Analysis, 27(2), 247-263. http://dx.doi.org/10.2307/2331370

Jensen, M. C., \& Meckling, W. H. (1976). Theory of the firm: Managerial behavior, agency costs and ownership $\begin{array}{llll}\text { structure. Journal of } & \text { Financial 305-360. }\end{array}$ http://dx.doi.org/10.1016/0304-405X(76)90026-X

Jiraporn, P., Kim, J. C., \& Kim, Y. S. (2011). Dividend payouts and corporate governance quality: An empirical investigation. Financial Review, 46(2), 251-279. http://dx.doi.org/10.1111/j.1540-6288.2011.00299.x

Kuo, J. M., Philip, D., \& Zhang, Q. J. (2013). What drives the disappearing dividends phenomenon? Journal of Banking \& Finance, 37(9), 3499-3514. http://dx.doi.org/10.1016/j.jbankfin.2013.05.003

Lang, L. H. P., Stulz, R., \& Walkling, R. A. (1991). A test of the free cash flow hypothesis: The case of bidder returns. Journal of Financial Economics, 29(2), 315-335. http://dx.doi.org/10.1016/0304-405X(91)90005-5

McManus, I., Ap Gwilym, O., \& Thomas, S. (2004). The role of payout ratio in the relationship between stock returns and dividend yield. Journal of Business Finance \& Accounting, 31(9/10), 1355-1387. http://dx.doi.org/10.1111/j.0306-686X.2004.00577.x

Miller, M. H., \& Modigliani, F. (1961). Dividend policy, growth, and the valuation of shares. In R. V. Howard \& M. Chris (Eds.), Elgar reference collection. pioneering papers of the Nobel memorial laureates in economics (Vol. 2, pp. 113-135). Cheltenham, U.K. and Northampton, Mass.: Elgar.

Miller, M. H., \& Rock, K. (1985). Dividend policy under asymmetric information. Journal of Finance, 40(4), 1031-1051. http://dx.doi.org/10.1111/j.1540-6261.1985.tb02362.x

Miller, M. H., \& Scholes, M. S. (1978). Dividends and taxes. Journal of Financial Economics, 6(4), 333-364. http://dx.doi.org/10.1016/0304-405X(78)90009-0

Myers, S. C., \& Majluf, N. S. (1984). Stock issues and investment policy when firms have information that investors do not have. Journal of Financial Economics, (13), 24. http://dx.doi.org/10.1016/0304-405X(84)90023-0

Rozeff, M. S. (1982). Growth, beta and agency costs as determinants of dividend payout ratios. Journal of Financial Research, 5(3), 249.

Stevens, J. L., \& Jose, M. L. (1992). The effects of dividend payout, stability, and smoothing on firm value. Journal of Accounting, Auditing \& Finance, 7(2), 213-216.

Wang, G. Y. (2010). The impacts of free cash flows and agency costs on firm performance. Journal of Service Science \& Management, 3, 10. http://dx.doi.org/10.4236/jssm.2010.34047

Wei, J. G., Zhang, W. G., \& Xiao, J. Z. (2004). Dividend payment and ownership structure in China. Advances in Financial Economics, 9, 22. http://dx.doi.org/10.1016/S1569-3732(04)09008-5

Wooldridge, J. M. (2010). Econometric analysis of cross section and panel data (10th ed.). Cambridge: MIT Press.

\section{Copyrights}

Copyright for this article is retained by the author(s), with first publication rights granted to the journal.

This is an open-access article distributed under the terms and conditions of the Creative Commons Attribution license (http://creativecommons.org/licenses/by/3.0/). 